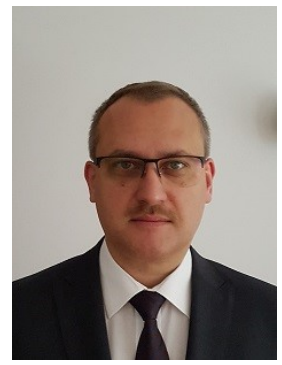

\title{
Pawel Cichoń
}

PhD, Chair of Administration History and Administrative Ideas Jagiellonian University

(Cracow, Poland)

*Corresponding author: e-mail: pawel.cichon@uj.edu.pl

\author{
"POLICE LAW" OF THE FREE CITY OF CRACOW \\ IN THE YEARS 1815-1846
}

„PRAWO POLICYJNE” WOLNEGO MIASTA KRAKOWA

1815-1846

\section{«ПОЛИЦЕЙСКОЕ ПРАВО» СВОБОДНОГО ГОРОДА КРАКОВ В 1815-1846 ГОДАХ}

\begin{abstract}
The aim of the article is to describe, on the one hand, the police authorities and, on the other hand, to present the tasks and competences implemented by these authorities in the field of public order and security in the Free City of Cracow (1815-1846). The legal bases defining the broad spectrum of police tasks were mentioned. These included the fight against begging, vagrancy, passport policy, population registration, protection of consumer interests and rights, building, sanitary and fire safety, maintenance of peace, cleanliness and order in Cracow and the fight against crime. Attention was also drawn to the reasons for issuing such rules of legal relations. In conclusion, the common features of "police law" acts and the meaning of the word "police" used in the Free City of Cracow were pointed out. The article was written using a formal-dogmatic method and a chronological-subject structure. It is the first and so far, the only scientific study presenting legal regulations concerning the title subject.
\end{abstract}

Keywords: law, police, administration, Free city of Cracow

\section{Streszczenie}

Celem artykułu jest scharakteryzowanie z jednej strony organów policyjnych, z drugiej zaś przedstawienie zadań $i$ kompetencji realizowanych przez te organy $w$ sferze porzadku $i$ bezpieczeństwa publicznego w Wolnym Mieście Krakowie (1815-1846). Wymieniono podstawy prawne określajace szerokie spektrum zadań policji. Dotyczyly one zwalczania żebractwa, włóczęgostwa, polityki paszportowej, ewidencji ludności, ochrony interesów i praw konsumentów, dbania o bezpieczeństwo budowlane, sanitarne, przeciwpożarowe, o utrzymanie spokoju, czystości i porzadku w Krakowie oraz zwalczania przestepczości. 
Zwrócono też uwage na przyczyny wydawania takich regulacji prawnych. W podsumowaniu wskazano na wspólne cechy aktów ,prawo policyjnego" oraz znaczenie słowa „policja” używanego w Wolnym Mieście Krakowie. Artykut zostat napisany przy zastosowaniu metody formalno-dogmatycznej oraz konstrukcji chronologiczno-rzeczowej. Jest to pierwsze i jak dotad jedyne opracowanie naukowe przedstawiajace regulacje prawne dotyczace tytułowego zagadnienia.

Stowa kluczowe: prawo, policja, administracja, Wolne miasto Kraków

\begin{abstract}
Аннотация
Цель статьи - описать, с одной сторонь, органь полиции, а с другой стороньл представить задачи и компетенции, осуществляемые этими органами в области общественного порядка и безопасности в Свободном городе Кракове (1815 -1846 г2.). Были упомянуты правовые основы, определяющие широкий спектр полицейских задач. $K$ ним относятся: борьба $c$ попрошайничеством, бродяжничеством, паспортная политика, регистрация населения, защита интересов и прав потребителей, строительство, санитарная и пожарная безопасность, поддержание мира, чистоты и порядка в Кракове, а также борьба с преступностью. Кроме того, было уделено внимание причинам возникновения таких правовых норм. В заключение были указаны общие черты «полицейского права» и определен смысл слова «полиция», используемого в Свободном городе Кракове. Статья была написана с использованием формально-догматического метода и предметно-хронологической структуры. Это первое и пока единственное научное исследование правовых норм, охваченных проблематикой данной статьи.
\end{abstract}

Ключевые слова: закон, полиция, администрация, Свободньй город Краков

Article history: Received: 20.06.2018 / Accepted: 25.06.2018 / Published: 30.06.2018 JEL Classification: N 4

\title{
The statement of the problem in general outlook and its connection with im- portant scientific and practical tasks.
}

The Free City of Cracow, also called the Republic of Cracow (1815-1846), was established at the Congress of Vienna, which defined the principles of the post- Napoleonic order in Europe. The act called the Additional Treaty of 3 May 1815, in which the signatory states (Austria, Prussia and Russia) established the "Free, Independent and Strictly Neutral City of Cracow together with the District", was of fundamental importance for the legal existence of this state. It was established under the protection of

the mentioned above guarding powers. The main objective of the protectors was to maintain the neutral and demilitarised status of the Republic of Cracow and to maintain and protect the existing political system of their countries, i.e. the absolute-police system, as well as to combat the threats that appeared in the region and destabilised the existing legal order. In accordance with Article 6 of the Treaty, the authorities of the Free City were obliged to avoid providing 
shelter or care to fugitives, deserters or persons under search who belonged to a signatory state of the agreement and to surrender such persons at the request of the competent authorities. Local authorities were also obliged to arrest such persons and deliver them under escort to the border for surrender to the competent guard of the neighbouring state (Kallas, M., Krzymkowski M., 2006, pp. 174-178).

In connection with such assumptions of the policy of the guarding states towards the
Republic of Cracow, a particular interest of these states as well as national authorities were issues related to the proper organization of local security services, i.e. the militia, gendarmerie and police authorities (Cichoń P., 2017, pp. 53-63). The latter performed numerous police and administrative tasks aimed at protecting public safety and order in the Free City of Cracow. Due to the framework of this study, only police authorities and their tasks will be described in the following section $(3,4,5,8,10,11,12)$.

\section{The analysis of the latest research when the solution of the problem was initiated.}

The sources of law concerning the Police. The sources of the law in force in the Free City of Cracow were not only legal acts issued by municipal bodies, i.e. the Senate acting as a government, or the Assembly of Representatives entrusted with the role of parliament (Wachholz Sz., 1957, pp.156157; Bartel W.M., 1976, pp.15-17). The organisation of the authorities of the Free City of Cracow and their powers were primarily influenced by the constitutional acts issued jointly by the guarding powers. However, issues concerning the organisation of the police services and their tasks in these constitutions were initially of marginal importance. Only Article 22 in the Constitution of 3 May 1815 (Kallas M., Krzymkowski M., 2006, pp. 179-182) and in the Constitution of 11 September 1818 (Kallas M., Krzymkowski M., 2006, pp. 183-190) pointed out the nature of the tasks of the municipal police, which were "the service of internal security and the police". On the other hand, the horse-riding gendarmerie was established to secure roads and rural areas. It was only in the Constitution of 30 May 1833 that a new Article 2 was introduced, in addition to the corresponding provision on the tasks of the militia and the gendarmerie (Article 26) which explicitly states that any individual or collective conduct directed "at transforming or confusing public order" existing in the states under the control of the three guarding powers, as well as any participation in such activities, would constitute a violation of strict neutrality and as such would be prosecuted and punished as a political offence by the national authorities. Moreover, there is an absolute ban on the admission of prosecuted persons, criminals and deserters and the obligation to surrender them at the request of the authorities of neighbouring countries (Kallas M., Krzymkowski M., 2006, p. 190201). In 1837, an additional article was introduced into the constitution (it was not numbered), which announced the liquidation of the institutions of vogts and subjudges. Their duties were to be taken over by the Police Directorate in Cracow, and those of the Police Commissioners (district commissioners) in the district (14). The term "internal security" used in the Constitutions of the Free City of Cracow was used to describe the nature of the security services, i.e. the police and gendarmerie. On the other hand, the term "public order" used in the Constitution of 1833 defined this "order" as a constitutional value protected by the state authorities. Detailed legal regula- 
tions concerning the organisation and operation of police services were contained in the Internal Equipment of the Senate of the Free City of Cracow and its District of 15 July 1816 , which defined the powers of the Police and Police Department of the same Senate and of the Intermediate Police Office. The department was to ensure, among others, public and personal safety, public morals, the quality and honesty of commercial practices, the medical police, cleanliness in the country and in the lighting of Cracow, as well as fire safety, and to prevent begging, vagrancy and to ensure compliance with Article 6 of the Additional Treaty (\$50) (15). In 1822, most of these tasks were taken over by a new department of the Senate, the Department of Internal Affairs and Police (Cichoń P., 2014, p.79). From the point of view of the police services organisation, the legal acts concerning the Police Directorate which took the place of the Intermediate Police Office in 1827 were of special importance. These were ordinances of the Senate: of 13 July 1827. (16) (hereinafter referred to as the PD's Statute), of 1 November 1833. (17) (Reorganisation of the police in the City of

\section{Aims of the paper. Methods.}

The article aims to present the institutional dimension of the Police and to present the tasks and competences of police authorities implemented in the field of public order and security in the Free City of Cracow (18151846). The article was written using the formal-dogmatic method and chronologicalobject construction. The official forms used were the "Journal of Government Regulations of the Free, Independent and Strictly Neutral City of Cracow and its District", "Journal of Laws of the Republic of Cracow", "Journal of Laws" and "Government
Cracow. The Instruction and the Limits of the same Authority, outlining - hereinafter referred to as the New Instruction), of 18 February 1840. (18) (hereinafter - Second Statutes of DP). Pursuant to para. 214 of the Second Statute of PD, the existing provisions contained in the Statute of PD of 1827 and in the New Instruction of 1833 "insofar as they contained provisions contrary to Part I of the new statutes, shall cease to be in force" (18). Apart from the above mentioned normative acts, a number of other detailed legal regulations defining the tasks of the police services were in force. The main purpose of these legal acts was to protect the narrowly defined problems of public order and security. These were mainly regulations of the Senate, which had the exclusive right to issue legal regulations related to the functioning of administration, including the police services. The Senate also issued instructions to the militia, gendarmerie and the police, setting out detailed rules for patrolling, carrying out searches and performing other activities related to public order and security (Cichoń P., 2014, pp. 55-71, 162-167, 238-248; Namysłowski W., 1914).

Gazette of the Free City of Cracow and its District". A source publication containing the text of the Constitution of the Free City of Cracow was also used. Not only were acts of "police law" identified in the legislation of the Free City of Cracow, but they were also subject to formal analysis and the reasons for issuing them were indicated. An attempt was also made to define common features of "police law" acts and to define the meaning of the word "police" used in the Free City of Cracow. 


\section{Exposition of main research materials with complete substantiation of obtained scientific results. Discussion.}

Organization of the Intermediate Police
Office and Police Directorate

The burden of actual performance of law enforcement and public security tasks in the Free City of Cracow was initially assigned to the Intermediate Police Office, also known as the Intermediate Police Agency. According to the internal arrangement of the Senate of the Free City of Cracow and its District of 15 July 1816, this body was established "to maintain the internal order of the city [of Cracow - P.C.], its resilience in operation and to ensure public peace and security". (§ 84) (19). The name of this body indicated the indirect role it was supposed to play in contacts between the government and other administrative bodies. Thanks to such location of the Office in the administrative structure, it was possible to ensure a quicker transfer of information, orders and commands between these authorities. It also made it possible to give government orders a more precise purpose, and to adapt the way they were arranged to real needs and organisational capabilities in the city of Cracow and its District.

According to the above mentioned regulation, the Intermediate Police Office was to include a police officer, an appropriate number of adjuncts, inspectors and other police officers, as well as a marked number of police soldiers ( $\$ 84)$ [ "middle-aged, sober, customary people, if they could write and read" could be admitted to the police service; the last condition was necessary for promotions to higher ranks in the mobile militia. Each soldier had to know personally all the officials and officials of the Intermediate Police Office, as well as the commune heads, in order to be able to receive oral orders from them in emergencies] (Namysłowski W., 1914, pp.34-35;
Wachholz Sz., 1957, p.286). The Intermediate Police Office was subordinate to the Militia and Police Department, and later to the Internal Affairs and Police Department, with the Police Authorising Officer also being obliged to carry out orders given directly by the entire Senate as well as by the President of the Senate (Cichoń P., 2014, pp. 80-81).

The most important police authority in the Free City of Cracow, which operated for nearly 20 years, was the Police Directorate (1827-1846). It was a body with many members and varied composition, which was subject to changes based on subsequent legal regulations concerning this body, i.e. the Statute of the Police Directorate of 13 July 1827. (20), the New Instruction of 1 November 1833. (17) and the Statutes of the Police Directorate of 18 February 1840 (18). Among the officers of the Police Directorate listed in these legal acts, we can distinguish - based on competence criteria - three categories of officers. The first group consisted of members of the Police Directorate who had independent or collective powers of authority related to the exercise of the competences of the Police Directorate. This group includes the police director, superintendents and adjuncts. The second group consisted of office workers who performed office functions. These were: secretary, journalist, archivist, clerk, registrar, cashier and controller, consignor, inspector. The third group of officers consisted of supervising service employees, which included: police inspectors, police junior inspectors, detective inspectors, detective junior inspectors, jail supervisors, guards, night guards, orderlies, fire officers, trumpeters at the fire brigade tower, executioners (Cichoń P., 2014, p.123). 
By virtue of the statute of $\mathrm{PD}$, the Police Directorate was divided into two units corresponding to two directions of its activity: court and supervision and administration (Wachholz Sz., 1957, p.301). As regards the functioning of these branches, the New Instruction of 1833 did not introduce any major organisational changes. The second Statute DPD of 1840 maintained the activity of the Judicial Division, also known as the Judicial Department.

On the other hand, the Administrative Branch was liquidated and replaced by the following principle

internal deconcentration and horizontal division of labour many separate positions: censorship officer, minutes secretary of the Registration Office and foreigners, passport secretary, construction referee (construction conductor) (Cichoń P., 2014, p. 212226).

The Trade Fair Commissioner, the writer of Servant's Bureau, as well as district commissioners and local superiors also cooperated with the Police Directorate. The Police Directorate was also provided with a police service consisting of delegated militia officers and gendarmes who guarded the detainees, carried out arrests and served at police stations (Cichoń P., 2014, pp. 227248).

\section{Tasks of police authorities}

The tasks of police authorities in the field of law enforcement and public security were very broad and thus regulated in numerous legislative acts. The implementation of these tasks was mainly related to the function of regulation and order. On the formal level, the borders of this protection were delineated by legal provisions indicating which authorities and in which situations could undertake sovereign interference, including those limiting the rights and freedoms of individuals. The law also regulated areas of social life which were subject to detailed legal regulations. On the other hand, the social and political role of public order and security meant that the regulations issued were purposeful and aimed at eliminating threats and ensuring the smooth functioning of society and the established legal order.

It is worth emphasizing that in the Free City of Cracow there was no legal definition of the terms "public order" and "public security". These terms determined the undefined tasks of the authorities in the Free City of Cracow and were a legal criterion for their actions, especially those of the police authorities. Both concepts belonged to, and still belong to, the so-called indefinite concepts, unclear expressions, the meaning of which is very extensible. Thanks to this, their use allowed for flexibility and adequate adaptation of their content to the changing internal situation in the country, especially to the political situation. On the other hand, it allowed for a relative stability of the existing law.

Analysing the en bloc legislation of the national authorities from the times of the Free City of Cracow, it can be concluded that maintaining public safety was to consist in maintaining the inviolability of life, health, dignity, honour, freedom, property and legal order. The scope of understanding of safety was strictly connected with the problems of occurring hazards. Thus, there was a clear coherence between them which caused that the nature and scale of the threats had an impact on the security of the individual, society and the whole state. The needs in this area, on the other hand, determined the choice of ways and methods of action which were to lead to elimination of these threats and achieve a state of lack of anxiety and peace. Public order, on the other hand, was to be ensured by the enforcement of legal provisions by the public, failure to comply with which, in conditions of collective coexistence, would expose them to dangers and nuisances. It was also 
connected with the protection against human carelessness and lack of predictions, and not only with the man's evil.

This range of police and administrative regulations in force in the Republic of Cracow was very large, therefore, in the following part of the article the most important tasks belonging to the police, resulting from these legal acts, will be presented.

One of the key tasks of the police services in the Free City of Cracow was to prevent and eliminate social pathologies, i.e. begging and vagrancy, which were common and posed a serious threat to public order. The first local regulations in this field were issued on 5 February 1817. Their aim was to protect the inhabitants of Cracow from the intrusion of the homeless and, on the other hand, to provide help in organized forms to the homeless and the unemployed. A general ban on vagrancy and begging was introduced, and police authorities were entrusted with the elimination of undesirable units from Cracow and its suburbs, as well as with drawing legal conclusions against perpetrators of such behaviour (21).

In the New Instruction of 1833, combating vagrancy and begging, which were still strictly forbidden, was entrusted to the Police Directorate. This legal act also styled minor offences in this category and specified penalties for their commission (Article 207, paragraph 70)(17). The ineffectiveness of the actions taken so far in the fight against begging caused that, on 3 July 1840 , the Government Senate issued a new regulation on this matter. This phenomenon continued to be combated by the Cracow Police Directorate and the district commissioners. Detained persons, depending on their origin and state of health, were sent to the Shelter House, the Forced Labour House (or to a branch office in Jaworzno) or expelled from Cracow or the whole country (Articles 9-12) (22).
Institutional combating with begging and vagrancy was with time connected with the Forced Labour House activity. According to the assumptions of the Act of 3 January 1822 , the homeless and the unemployed who were capable of physical work were detained in the house (Article 1) (23). This house remained under the supervision of the Police Directorate and was a prison facility. The stay in it was to contribute to the increase of the moral level, to the re-education of people that were unproductive and prone to misdeeds. It was also supposed to help them develop the habit of honest work for their own livelihood.

Another task of the police services was to implement an appropriate passport policy, including the issuance and affixing visas for passports. In this respect, from 1827 a very important role was played by the Police Directorate and its director who personally issued and signed each passport (the secretary of the Police Directorate also signed passports). These legal instruments were very important as the visa requirement made the possibility for foreigners to stay in the Free City of Cracow which was tantamount to recognize that they did not pose a threat to the existing legal order. On the other hand, receiving a passport by a citizen of the Republic of Cracow allowed such citizen to travel to neighbouring countries or to continue the journey. From the 1930s, passport rules were systematically tightened up. In 1832, the Government Senate issued regulations to prevent the use of passports by unauthorized persons. Criminal liability for attempting to give the passport to another person as well as for using the passport of another person was also introduced (item 1). It also provides for legal consequences for persons who, through negligence or recklessness, contributed to the theft or loss of their passports (Article 4) (24). The New Instruction of 1833 introduced further passport restrictions. The 
travel document could only be obtained by persons who had presented a certificate of good repute from their home municipality (Article 40) (17). Moreover, the Police Directorate was obliged to send daily lists of foreigners arriving in and departing from Cracow to residents of Austria, Prussia and Russia (Article 41). The aim of these legal changes was to minimize the risk of arriving and departing abroad by people who, due to their previous criminal, underground or independence activities, were undesirable in neighbouring countries. Therefore, a strict passport policy was to contribute to more effective protection of public order and security in Austria, Prussia and Russia, which the authorities of those countries cared for very much (Cichoń P., 2014, p. 273-277). The new Instruction of 1833 also contained an additional catalogue of police and administrative offences related to the misuse of passports (Article 207, items (83) to (85)) (17).

During the occupation of the Republic of Cracow by the armies of the guarding powers from February 1836, even stricter passport regulations were introduced, which were justified by the impossibility of maximising the protection of public safety in the region (25). Also, the Second Statute of PD of 1840 provides for an important role of the Police Directorate in the implementation of the passport policy in line with the expectations of the guarding powers ( $§ 59$, 90-94)(18). Furthermore, on 15 March 1841 the Government Senate issued a decree prohibiting persons from leaving the country without a passport and from voluntarily extending their stay abroad beyond the time limit laid down in their passports (26).

Another task of the police authorities was to control the movement of people within the country. The first regulations concerning the population register in the Free City of Cracow were issued on 29 August 1816, therefore certain tasks in this respect were imposed on the Intermediate Police Office and on the heads of rural communes. The means used for this was the maintenance of a population book, based on a broadly defined registration obligation. This allowed administrative and police authorities to obtain, collect and process information relevant to public security, including the fight against vagrancy and the detention of suspected or wanted persons. The New Instruction of 1833 redefined the registration bundles and the recording tasks of the Police Directorate (Articles 106-122) (17). In 1836 there was a republishing of the registration regulations of 1824. (27). From 1837, the role of the Police Directorate in the performance of recording duties significantly increased, and the obligation to register in Cracow was fulfilled only in this area, excluding the heads of villages (28) [Absolute enforcement of registration regulations was in the interest of both local authorities and the guarding powers. The implementation of this obligation became particularly important during periods of military intervention and occupation undertaken by the guarding powers, and the increased criminal sanctions for failure to comply with registration obligations were to discipline people for their implementation. In addition, the Police Directorate and, in the district, the district heads, and later the district commissioners, were entrusted with the task of enforcing the police regulations laying down the curfew and the rules for moving on the streets after dark (Cichon P., 2014, pp. 289-290).

The Free City of Cracow issued numerous legal regulations concerning the activities of small and medium-sized enterprises, especially commercial and service ones. The aim of these provisions was not only to maintain order in this area, but also to improve the safety of economic transactions and protect public life, health and morals. 
This involved, inter alia, issuing permits to carry out such activities subject to the sometimes very detailed conditions set out in those provisions. This included running inns (29), playing music in them - which was an instrument for combating drunkenness (30), employing women in such places - to combat illegal prostitution (31), running boarding schools for youth (32), selling grain (33), fuel (34), alcohol (35), etc. Such legal acts also contained provisions regulating the competence and procedure of introducing control over the conducted activity and the quality of sold goods and provided services (Cichoń P., 2014, pp. 308318). An important instrument which assisted in the performance of the trade inspection function was the transfer to the police administration of the power to inspect measuring instruments used in trade and, from 1836, the power to legalise them (36). In addition, the 1845 legislation introduced administrative supervision over the sale of jewellery which was intended to prevent the illegal sale of those products from abroad (37).

The police services were also responsible for carrying out construction supervision. The aim of such activities was to prevent the unauthorized execution of renovation and construction works in Cracow, which was dictated not only by the desire to avoid threats in the form of construction disasters but also by the maintenance of aesthetics and architectural order in the City. The Police Directorate was also entrusted with supervisory powers in this area and was to ensure that construction work and chimneysweeping services were carried out by suitably qualified persons (Articles 155 to 156) (17).

Pursuant to a decree of the Senate of 18 February 1842, the Police Directorate additionally controlled the quality of building materials that were produced and sold in the City as well as imported into the country. It provides for very restrictive sanctions for the sale of non-standard materials, including their confiscation ( $(4-6,7,14-15)$ (38). The New Instruction of 1833 also introduced a new category of tasks related to ensuring "public calm", which directly contributed to maintain public order and security in the Free City of Cracow. In this respect, the Police Directorate was to take care of peace and order in public places, prevent verbal incidents and other illegal behaviours. An obligation to register associations has also been introduced, but only after having ascertained their usefulness and fairness (Articles 123 to 124) (17).

Moreover, the Police Directorate, together with the Censorship Committee, supervised printing, lithographic and bookshop companies. Its aim was to track down forbidden publications, which had a particularly negative impact on the existing political situation in the country and its dependence on guarding powers (Articles 125-126)(39).

This coincided with the introduction of legal regulations for the performance of shows, plays and also the organisation of public gatherings. In order to be allowed to do so, it had to be verified in advance whether the content or the agenda 'contains nothing of such a kind as to offend or harm the religion, morals or interests of the country as well as its neighbours' (Articles 127130) (39).

The police were also to secure the peaceful course of state ceremonies, as well as social events, both private and official (Articles 132-134) (e.g. in January 1830, the Police Directorate, in accordance with the decision of the Department of Internal Affairs and Police of 24 January 1830, issued "Regulations for maintaining order on public balls in the Free City of Cracow"). (Cichon P., 2014, p. 326)].

The New Instruction of 1833 also contained provisions to protect the safety of persons 
and their property. A general ban was introduced on the carrying of weapons in public places, including white weapons in the form of blades hidden in objects without the appearance of a weapon, as well as daggers and guns. Violators of this prohibition were subject to criminal liability (Articles 135148) (17).

The New Instruction of 1833 also provided for instruments aimed at protecting the life and health of Cracow's inhabitants, i.e. the official designation of safe swimming pools on the Vistula and Rudawa (separate for men and women - Articles 137-138). There is also provision for administrative supervision of order, cleanliness and safety in public baths, as well as of their equipment ('ringtones for bathers' weakness' - Article 147)(17).

The legal acts also specified the mode and scope of control of entertainment establishments and accommodation facilities. The main objective of these activities was to pursue the detection of suspects, people who were wanted or illegally present on national territory (Article 144).

Legislation has also been introduced to protect young people from demoralisation, including a ban on attending drinking and entertainment facilities as well as brothels. Administrative supervision over the running and opening of bars, inns and billiard houses was envisaged. Illegal gambling was also combated and prostitution, which was to some extent allowed, was controlled (Articles 141-146)(17).

In case of emerging threats related to the risk of occurrence of infectious diseases, there were also provisions imposing common obligations related to prevention and control of such threats [the Police Directorate played an active role in combating the cholera epidemic that occurred in Cracow in 1831 (Bieniarzówna J., Małecki J.M., 1979, pp. 78-79)]. This also applied to the control of animal disease epidemics, e.g. through the introduction of quarantine within a defined area or temporary restrictions on cattle trade (Cichoń P., 2014, pp. 321-324).

An important aspect related to the protection of life and health of the inhabitants was the care for the proper sanitary condition of water intakes (Article 139). The New Instruction of 1833 also contains extensive health safety provisions relating to prohibition on the sale of premature fruits, dead fish, rotten meat, unroasted bread, etc., which are harmful to health. (Article 180). The Police Directorate was obliged to immediately notify the Department of Internal Affairs and the Police in the ruling Senate of any death caused by a contagious disease to take measures to protect against the epidemic (Article 182) [Preventive measures were also taken, e.g. vaccination against smallpox. The rules concerning the vaccination against smallpox were published in the Government Gazette WKM 1842]. (40). Another task of the police services was to take care of cleanliness and order in Cracow. The first legal regulation which provided for certain obligations of the police in this respect was the Regulation of $15 \mathrm{No}$ vember 1816. "Ordinance of willingness and order in the City of Cracow, binding on the owners of houses or their deputies to preserve", Government Gazette 1816, this regulation was published separately (no journal number), no. 816). Additional provisions regulating the obligations related to maintaining cleanliness on streets and public squares in Cracow were issued on 9 May 1833. (42). The New Instruction of 1833 also sets out a number of related tasks (Articles 183-190). A number of light police offences were also identified, related to breaches of rules related to maintaining cleanliness in the city, including street cleaning and clearing snow from roofs and streets (Article 207, paragraph 59). Another manifestation of concern for order in the 
city, as well as for protection against unpleasant odours, was the control by the Police Directorate of illegal livestock breeding in Cracow (Article 207, items 62-64) (17).

Much attention was also paid in legal acts to issues related to the so-called fire police, i.e. fire safety. In Cracow, as part of the Austrian fire regulations of 22 April 1803, the Senate issued two orders in April and May 1818 concerning the organisation of a fire service in Cracow and the location of barrels and water tankers (Wachholz Sz., 1957, p. 383).

The New Instruction of 1833 also contains a number of regulations concerning fire protection. Among other things, it was forbidden to store flammable materials in wooden rooms or to smoke in public places or to use open fire in places such as stables, mobile homes, inns, alcohol shops, etc. under penalty. It was also recommended to set up stables in rooms with brick vaults with permanently installed lanterns (Articles 157 to 163) (17). Legal regulations also provided for personal obligations related to participation in fire extinguishing and possession of appropriate firefighting equipment (Article 207, items 80, 98-100). Enforcement of such obligations by the police services was to increase the effectiveness of firefighting actions, and at the same time raise public awareness related to the existence of personal obligation to participate in firefighting action by the owners of houses located in the immediate vicinity of the fire or by their servants (Cichon P., 2014, p. 307).

The Austrian fire regulations of 1803 were in force until 1842, when they were replaced by a new regulation of 6 December 1841 entitled 'Fire equipment for the Free City of Cracow and its District' (43). These regulations governed, among others, the issues of fire prevention, as well as the organization and course of rescue and fire- fighting operations and securing the belongings of fire victims. A number of obligations for police officers were also defined.

An important task of the police services was also the fight against crime. Investigative activities in Cracow were carried out by the Intermediate Police Office, and later by the Police Directorate, and in the Cracow district by the mayor, and over time by district commissioners (Article 2, Article 12) (Cichoń P., 2014, p. 81)(44). From 1839 the Police Directorate undertook such activities also in the cases of crimes that took place within the communes administratively incorporated into Cracow. It was also entrusted with judicial powers in cases of serious police offences at that time. The amendments to the rules on the organisation of the judiciary were justified by the fact that they aimed to increase internal security in the country and in neighbouring countries (45). Moreover, the Second Statute of the PD of 1840 specified that its powers included adjudicating on all cases of serious crimes committed within the City and administrative communes incorporated in Cracow (§ 14)(18). In contrast, from 1842, the Police Directorate was granted exclusive powers of investigation and adjudication in serious offences affecting public safety, public peace and civil or military guarding images $(\S 18,73)(46)$ (Cichoń P., 2014, p.360). This also applied to censorship cases, provided they were not crimes [Under the organic statute for the judicial authorities of the Free City of Cracow of 25 January 1842]. (47). The material legal basis for the judicial activity of the Police Directorate was the Austrian Criminal Code Part 2 of 1803 in force in the Free City of Cracow [the Austrian Criminal Code of 1803 in the Free City of Cracow was used in Polish translation] (48).

According to the New Instruction of 1833 , crime prevention was also associated with 
the supervision of prisoners leaving prison which was supposed to discourage them from returning to criminal activity. Another form of preventive activity was the control of itinerant trade which was intended to prevent dealing in stolen goods and petty theft, which were committed mainly by the servants, and by young people (Articles 140, 148 to 149$)(17)$.

It is worth noting that the effectiveness of police activities depended on the enforcement of legal liability towards persons who violated the regulations in force in this respect. The level of penalties for such violations is set by law in relation to specific violations of the law. Both the financial penalties and the rates of imprisonment or caning varied for different acts. This concerned e.g. unreliable conducting of business activity, failure to comply with the registration obligation, violation of police regulations, fire safety regulations, unfair commercial practices, failure to comply with the obligation to participate in firefighting activities, etc. (e.g. Article 207, items 1 to 101)(17). The introduced system of administrative sanctions, defined in a detailed

\section{Conclusions.}

Summarizing the above considerations, it can be noted that "police law" was not codified but scattered and covered many legal acts, and at different levels. The abovementioned "police law" acts contained both political provisions concerning the organisation of police services as well as substantive provisions defining various types of activities, both preventive and repressive. These acts also contained provisions laying down criminal sanctions for infringements of the rules on law and order. Therefore, a characteristic feature of these legal regulations was also the interpenetration of elements of administrative supervision over a specific area of social life with criminal-administra- manner, resembling modern mandate tariffs, provided an opportunity to improve the effectiveness of enforcement of legal administrative obligations incumbent on various entities. In most cases, these were fines, the amount of which increased if the same offence was committed again. In some cases, the penalty for committing the same offence three times was a ban on continuing to operate, for example, in a commercial or service capacity (49). Continuing to commit the same offences gave rise to liability under the Criminal Code (17a). In the case of offences related to offering goods of poor quality or not in accordance with official contribution or goods coming from illegal sources, the penalty of confiscation was applied (17b). The most severe punishment for foreigners was their expulsion from the Free City of Cracow (32a). The New Instruction of 1833, which provided for 101 types of minor offences in Article 207, had special importance for the enforcement of administrative obligations by police services.

tive elements related to the granting of powers to police authorities to impose such sanctions for infringements of the law.

The aim of so many 'police law' acts was to protect public interests and the various aspects of a peaceful and safe life. However, some of them were politically justified due to the legal dependence of the Free City of Cracow on the guarding powers, i.e. Austria, Prussia and Russia. This was particularly the case with regard to the use of passports and movement controls. Since the 1930s, there has been a trend towards centralisation and concentration of competences in the field of maintaining public order and security. Most of the tasks in this 
field were transferred to the Police Directorate, which from 1836 was already managed by Austrian directors who were also officially guided by the guidelines issued by the representatives of the guarding powers (Cichoń P., 2014, p.140). In this sense, the Police Directorate became a monopoly in the protection of public peace, order and security and served to strengthen the police model of the state.

Finally, it is worth noting that the word "police" used during the period of the Free City of Cracow had first of all a physical meaning (similar to that used in the second half the Police Directorate and their officers. of the 18th century) and defined the tasks of the so-called administrative police, which ex definitione was to secure various areas of social life and to ensure the stability of social relations. As a result, various departments of the administration have pervaded police functions. The word "police" also appeared in a subjective sense, identifying the authorities that performed administrative and police functions, i.e. the Police and Police Department, the Internal Affairs and Police Department, the Intermediate Police Office.

\section{References:}

1. Bartel W.M., (1976) Ustrój i prawo Wolnego Miasta Krakowa (1815-1846), Kraków, Biblioteka Krakowska, nr 116.

2. Bieniarzówna J., Małecki, J.M., (1979) Kraków w latach 1796-1918, Kraków, Dzieje Krakowa, t. 3.

3. Bełcikowski J., (1923) Żandarmerja Wolnego Miasta Krakowa (1815-1846), „Polska Zbrojna” R. 3 nr 82, s. 4-5.

4. Chudzio H., (2008) Milicja Wolnego Miasta Krakowa 1815-1846, [w:] „Policjanci. Policyjny Magazyn Historyczny" nr 1, s. 38-42.

5. Cichoń P., (2012) Przyczynek do dziejów Żandarmerii Wolnego Miasta Krakowa, [w:] Regnare Gubernare Administrare Z dziejów administracji, sądownictwa i nauki prawa prace dedykowane profesorowi Jerzemu Malcowi z okazji 40 lecia pracy naukowej, Kraków, s. 55-71.

6. Cichoń P., (2014) Dyrekcja Policji Wolnego Miasta Krakowa 1827-1846. Studium historyczno-prawne, Kraków.

7. Cichoń P., (2017) Wplyw mocarstw opiekuńczych na organizację $i$ działalność stużb policyjnych $w$ Wolnym Mieście Krakowie (1815-1846), [w:] Pogranicza w historii prawa i myśli polityczno-prawnej, Gdańsk, Olsztyn, s. 53-63.

8. Gepner S., (1937) Milicja krakowska, [w:] „Broń i Barwa” R. 4, nr 3, s. 4-5.

9. Kallas M., Krzymkowski M., (2006) Historia ustroju i prawa $w$ Polsce 1772/1795-1918. Wybór źródeł, Warszawa.

10. Louis J., (1882) Dawna milicya krakowska, [w:] „Kalendarz Krakowski” R. 51.

11. Namysłowski W., (1914) Milicya Wolnego Miasta Krakowa 1815-1846 Kraków, Biblioteka Krakowska nr 48.

12. Pacek P., (2004) Żandarmeria wojskowa na ziemiach polskich $w$ latach 1815 1831, Warszawa.

13. Wachholz Sz., (1957) Rzeczpospolita Krakowska. Okres od 1815 do 1830 r., Warszawa. 


\section{Legal acts:}

14. Dziennik Praw 1837, nr 5436 D.G.S., s. 1-5 (dalej Dz. Praw).

15. Dziennik Rozporządzeń Rządowych Wolnego, Niepodległego i ściśle Neutralnego Miasta Krakowa i Jego Okręgu, 1816 ,nr 2104 (dalej Dz. Rozp. Rządowych WMK).

16. Dziennik Praw Rzeczpospolitey Krakowskiey 1827, nr 3344 D.G.S. (dalej Dziennik Praw RK).

17. Dz. Praw 1834, nr 2736 D.G.S.

a. $\quad$ art. 207, pkt 33, Dz. Praw 1834, nr 2736 D.G.S.

b. art. 207, pkt. 3,4,7, 13, 40, Dz. Praw 1834, nr 2736 D.G.S.

18. Dz. Praw 1840, nr 10 D.K.

19. Dz. Rozp. Rządowych WMK 1816, nr 2104.

20. Dz. Praw RK 1827, nr 3344 D.G.S.

21. Dz. Roz. Rządowych WMK 1817, nr 386.

22. Dz. Praw 1840, s. 1-2, nr 287 D.G.S.

23. Dz. Roz. Rządowych WMK 1822, nr 58 D.G. Faktycznie został utworzony dopiero na mocy rozporządzenia Senatu z dnia 15 VI 1827 r., Dz. Praw RK 1827, nr 3999.

24. Dziennik Rządowy Wolnego Miasta Krakowa 1832, nr 31, s. 125-127, nr 5024 D.G.S. (dalej Dz. Rządowy WMK). Ponowna publikacja tych przepisów nastąpiła w Dz. Rządowym WMK 1835, nr 46-47, s. 180-182, nr 7054 D.G.S.

25. Dz. Praw 1836, nr 6908 D.G.S.

26. Dz. Praw 1841, nr 1492 D.G.S.

27. Dz. Rządowy WMK 1836, nr 11-12, s 42-43, nr 1421 D.G.S.

28. Dz. Rządowy WMK 1837, nr 33-34, s. 129-131, nr 1095 D.G.S.

29. Dz. Praw 1839, nr 3388 D.G.S.; Dz. Praw 1839, nr 7009 D.G.S.

30. Dz. Rządowy WMK 1831, nr 2, s. 5-7, nr 2927 D.G.S.; Dz. Rządowy WMK 1939, nr 15-16, nr 1167 D.G.S.

31. Dz. Rządowy WMK 1829, nr 9, s. 35-36, nr 929.

32. Dz. Praw 1842, nr 5271 D.G.S.

33. Dz. Rządowy WMK 1830, nr 12-13, s. 45-48, nr 1168. 